\title{
Maturity Level for IT Implementation Measurement Focus on Business Goal 14 and 15 at Diskominfo Province
}

\author{
$1^{\text {st }}$ Siti Mukaromah \\ Information Systems \\ Universitas Pembangunan Nasional \\ "Veteram" Jawa Timur \\ Surabaya, Indonesia \\ sitimukaromah.si@upnjatim.ac.id \\ $4^{\text {rd }}$ Eva Y Puspaningrum \\ Informatics \\ Universitas Pembangunan Nasional \\ "Veteram" Jawa Timur \\ Surabaya, Indonesia \\ evapuspaningrum.if@upnjatim.ac.id
}

\author{
$2^{\text {nd }}$ Cyndya Nandhany \\ Information Systems \\ Universitas Pembangunan Nasional \\ "Veteram" Jawa Timur \\ Surabaya, Indonesia \\ cyndyaanandhany@gmail.com \\ $5^{\text {th }}$ Novianto Puji Raharjo \\ Islamic Communication and \\ Broadcasting \\ Institut Agama Islam Darrullughah \\ Wadda'wah \\ Pasuruan, Indonesia \\ nopy.pr@gmail.com
}

\author{
$3^{\text {rd }}$ Namira Abda Taqiya \\ Information Systems \\ Universitas Pembangunan Nasional \\ "Veteram" Jawa Timur \\ Surabaya, Indonesia \\ namiraabda@gmail.com \\ $6^{\text {th }}$ Doddy Riddwandono \\ Information Systems \\ Universitas Pembangunan Nasional \\ "Veteram" Jawa Timur \\ Surabaya, Indonesia \\ doddyridwandono.si@upnjatim.ac.id
}

\begin{abstract}
How Information Technology and Information System (IT/IS) has been implemented at an organization or institution needs to measure to evaluate IT/IS implementation. Nowadays, IT is compulsory in business processes. It helps the employee to handle some of their duty. But it needs to measure to monitor how IT/IS aligns with the business. So, that management could decide whether IT/IS is maintained or need to be upgraded or else. There are many ways to measure IT/IS implementation; this article will discuss the maturity level based on Cobit 4.1. It will measure per level from level 0 to level 5. The scope of this research is at business goal 14 and business goal 15 and a case study of this research in Diskominfo at one of the provinces in Indonesia. The result of this research is the maturity level of Business Goal 14, and Business Goal 15 is in Level 3, it means that Define Process.
\end{abstract}

Keywords—cobit 4.1, maturity, bg14, bg15.

\section{INTRODUCTION}

In this modern era, we could not be separated from technological advantages. IT/IS is implemented in all business areas, from the small business area to wide-open business areas. IT/IS that developed to handle some business processes should be proper as an application [1]-[5].

It is said by Solow [6] that at that time, computer development at that time was very fast but not matched by economic development. From that phenomenon, it needs to find where the problem is. In order to find the problem, IT should be managed.

Whether IT/IS is just complementary or, moreover, as a compulsory business process, if IT/IS is just complementary at the business process, it's simply concluded that IT productivity paradox would have occurred.

IT productivity paradox shows that IT/IS that has implemented at business is just a parasite, it spends more money (IT investment) rather than contribute more money [7] in other words, says that imbalance between IT investigation and organization productivity. Why the IT productivity paradox takes place, it because of miss measurement, redistribution, time lags, and miss management. [8], [9]

In order to avoid the IT productivity paradox, the organization needs to measure IT/IS implementation regularly. There are so many ways to measure IT/IS implementation; one of those IT/IS implementation measurements is to find maturity level based on Cobit 4.1.

A good IT governance can be focused on five areas; they are strategic alignment, resource management, value delivery, performance measurement, and risk management. So that IT that implemented should be managed as good as possible, in order IT not just as a compliment but also as an enabler of business processes.

Cobit 4.1 is an IT governance framework is suitable to measure IT implementation maturity. Cobit 4.1 has four domains; they are Plan and Organise (PO), Acquire and Implement (AI), Deliver and Support (DS), and Monitor and Evaluate (ME). PO has 10 IT processes, AI has seven IT processes, DS has 13 IT processes, and ME has four IT processes, so overall, Cobit 4.1 has 36 IT processes.

Diskominfo province is one of the government communication offices at the provincial level, who plays a role in assisting the Governor in preparing the materials needed in government affairs in the field of communication and information. Diskominfo province plays a role in assisting the Governor in preparing the materials needed in government affairs in the field of communication and information

In this article, the research question is how to measure maturity level at business goals 14 and 15 . From the finding of maturity level, it can be seen which level of readiness IT/IS 
implementation [10]. The result of the maturity level; can recommend some recommendations based on Cobit 4.1 and the applicable regulations.

\section{LITERATURE REVIEW}

\section{A. Information Systems}

Information System is a technology that can manage the daily business process. An information system is made to help the organization to increase profitability; it also can gain the relationship between a customer or their relations. [1]-[5], [11]

A good information system should be well developed. It starts with analysis, design, development, testing, and implementations. [12], [13]

\section{B. IT Governance}

IT Governance is a process that ensures the effective and efficient use of IT in enabling organizations to achieve their goals. IT Governance has five focus area, they are: [10], [14][17]

1) Strategic alignment: it manages how IT operations should align with business operations. It manages from IT plans on the organizations, how it's defined, how to acquire IT, how to deliver IT, and how to maintain IT. In order to sustain IT results, a good combination of Strategy, operation, and culture must be established. Henderson and Venkatraman [18] publish a model of IT Strategic Alignment:

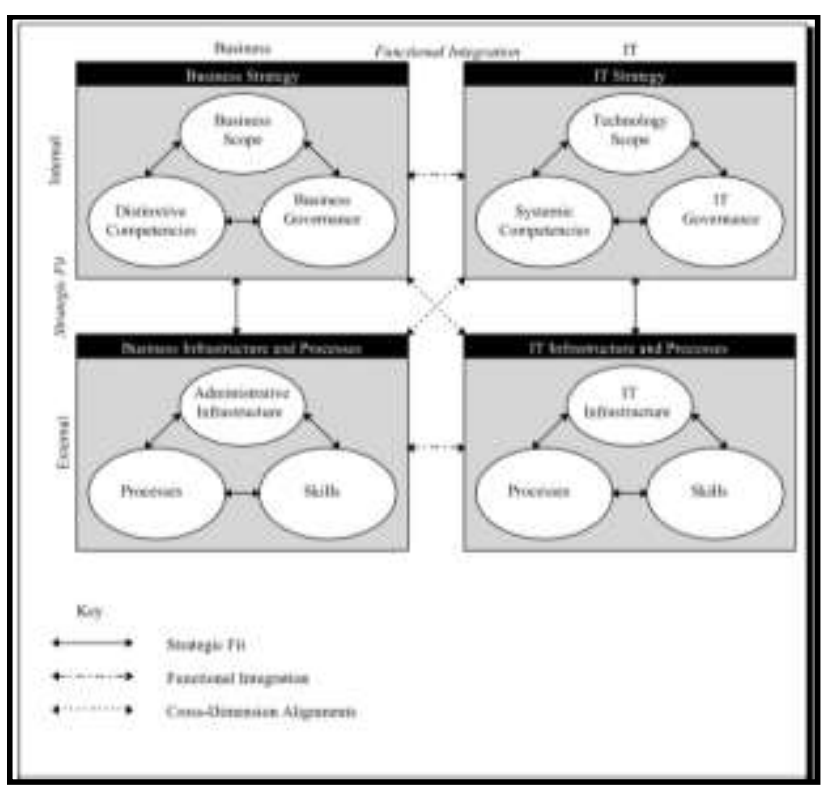

Fig. 1. IT Strategic Alignment (Henderson, Venkatraman)

Business Strategy:

- Scope of business - options relating to product-market offerings,
- Distinctive competencies - the strategic attributes that contribute to distinctive, comparative advantage over other competitors, and

- Governance functions - choice of structural mechanisms for regulating business operations that recognize a continuum between markets and hierarchy.

Organizational Infrastructure and Processes:

- Administrative infrastructure - including organizational structure, reporting roles and relationships,

- The process of articulating workflows and related information flows to carry out major activities, and

- Individual and organizational skills to carry out the main tasks that support the business strategy.

Information Technology Strategy:

- The scope of information technology types and the range of IT systems and capabilities potentially available to the organization;

- Systemic competence - focuses on the distinctive attributes of IT competencies that contribute positively to the creation of new business strategies or better support of existing business strategies, and

- IT Governance - refers to the choice of Strategic Alignment: A Model for the Transformation of Organizational structural mechanisms to obtain the required IT capabilities, involving issues such as proprietary vs. public network deployment.

Information Technology Infrastructure and Processes:

- Architecture - options relating to application, data, and technology configuration

- Processes - relating to the work processes of the IT infrastructure operation center, including processes for system development, maintenance, and monitoring and control systems, and

- Skills - options relating to the knowledge and abilities required to manage IT infrastructure effectively in an organization.

2) Value Delivery: something that expected users of an IT/IS service. How IT deliver maximum value to all stakeholder (values are different for each stakeholder). IT could create value for stakeholders by Faster delivery time, Secured control for IT risks, Better service quality, and Cheaper service cost.

3) Performance Measurement: To justify IT investment, whether IT contributes to the overall performance of the company. Enables management to assess, adjust, \& make decisions regarding IT investment \& IT Strategy. Allows management to Monitor \& Manage IT Performance. Monitor

International Journal of Computer, Network Security and Information System (IJCONSIST)

Vol: 2, Issue: 2, March 2021, pp. 45-52 
IT-related costs and makes informed decisions regarding the utilization of IT resources. Evaluate $\&$ assess the priorities of IT projects. The same 'language' of IT personnel and management in general: 'profit,' 'cost,' 'return on investment,' etc.

4) Resource Management: The process of allocating \& utilizing the organization's IT resources in the most efficient manner possible but capable of achieving organizational goals (Effective). Includes: IT Investment Management, Outsourcing Management, Asset Management, Configuration management

5) Risk Management: With more of the organizational value proposition being built on IT, the risks associated with IT are often the same as the business risks. The IT risks include Security risks arising from hacker attacks, Privacy risks arising from identity theft, disaster recovery, system resilience from outages, and risks associated with project failure.

\section{Audit Information System}

Information Systems Audit is a systematic process of collecting and evaluating evidence to determine that a computer-based information system used by the organization has achieved its objectives. [7], [10], [14]-[16], [19]-[26]

\section{Cobit}

Control Objective for Information \& Related Technology (COBIT) is a collection of best practice documentation for IT Governance that can help auditors, users, and management, to bridge the gap between business risks, control needs, and IT technical issues. Cobit is a guideline from the IT Governance Institute. [7], [10], [14]-[16], [20]-[22], [24]-[26]

\section{RESEARCH METHODOLOGY}

In order for this research could reach its goal, it needs to do step by step of the research methodology. There are a couple of steps to accomplish this research

\section{A. Audit Planning}

An audit is needed to scheduled regularly in order to review capturing applicable evidence-based on auditing procedures.

\section{B. Objective and Scope}

An audit scope as boundaries described by processes to be reviewed. The scope in this research is at one of province diskominfo in Indonesia. It will be focused on business goal 14 and business goal 15 . The objective of this research is to find the maturity level of business goal 14 and business goal 15 .

\section{Assigning Roles and Responsibilities}

We are conducting roles and responsibilities. In this step, we have to mapped the role at diskominfo province and adjust it to the RACI chart that Cobit 4.1 has already prepared.

\section{Conducting Audit}

At this stage, the audit information system is held, performing an assessment. Collecting some evidence, do some interviews with the responsible person according to the RACI chart. From that information, then we could fill the audit working paper and find the result. If the results have been found, the next step is to provide recommendations according to the results obtained in order to improve service processes and productivity in providing services to the community based on applied IT.

\section{RESULTS AND DISCUSSIONS}

The result of this research is followed by this step:

\section{A. Objective and Scope}

The objective of this research is to measure the maturity level at business goal 14 and business goal 15. The scope of this research is based on mapping by cobit 4.1 itself.

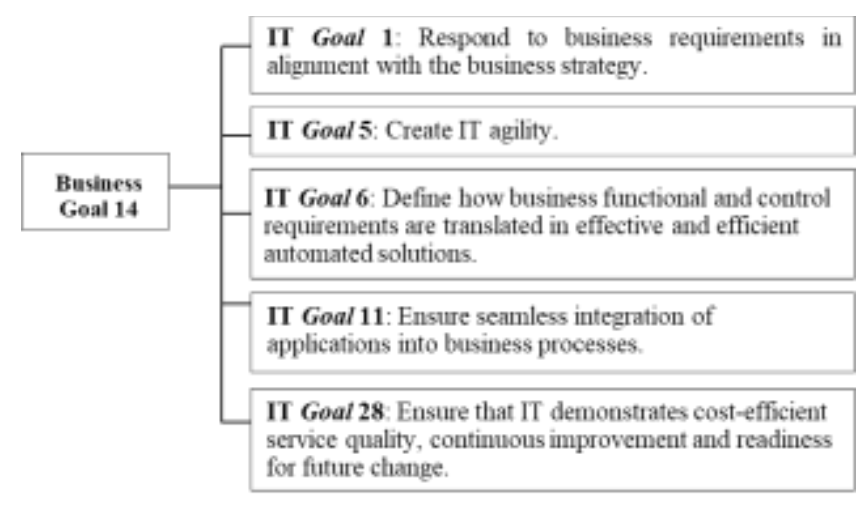

Fig. 2. Mapping BG14 to ITG

The mapping of Business Goal 14 to IT Goal that is already mapped by cobit 4.1 , as seen in Figure 2. Business goal 14 has 5 IT goals to be measured; they are IT goal 1, IT goal 5, IT goal 6, IT goal 11, and IT goal 28.

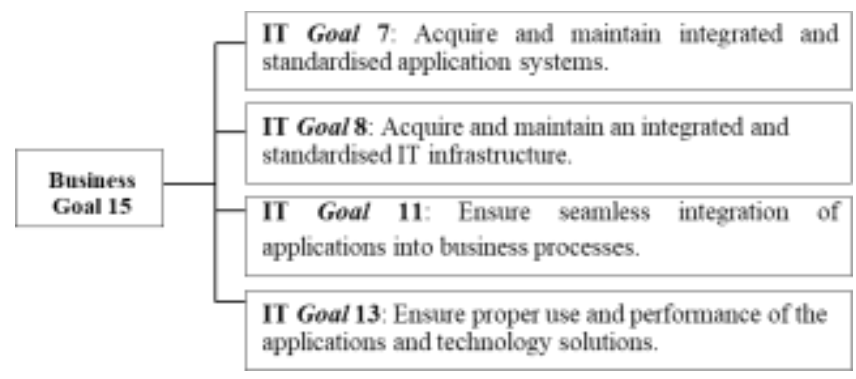

Fig. 3. Mapping BG15 to ITG 
Figure 3 shows that the mapping of Business Goal 15 to IT Goal that is already mapped by cobit 4.1. Business goal 15 has 4 IT goals to be measured; they are IT goal 7, IT goal 8, IT goal 11, and IT goal 13 .

\section{B. Assigning Roles and Responsibilities}

Here are the mapping of responsibilities and role in the case study. The response is from the RACI chart, and the role is a position or role at diskominfo province, as seen in table 1 .

TABLE I. MAPPING RESPONSIBLE AND ROLE

\begin{tabular}{|c|c|c|c|}
\hline No & Responsible & $\begin{array}{c}\text { IT } \\
\text { Process }\end{array}$ & Role \\
\hline 1 & $\begin{array}{l}\text { Chief } \\
\text { Architect }\end{array}$ & $\begin{array}{l}\text { PO2, } \\
\text { PO3, } \\
\text { AI3, } \\
\text { DS8 }\end{array}$ & $\begin{array}{l}\text { Head of } \\
\text { Diskominfo } \\
\text { Province }\end{array}$ \\
\hline 2 & $\begin{array}{l}\text { Head } \\
\text { Development }\end{array}$ & $\begin{array}{l}\text { PO2, } \\
\text { AI2, } \\
\text { AI3, } \\
\text { AI4, } \\
\text { AI5, } \\
\text { AI7, } \\
\text { DS8 }\end{array}$ & $\begin{array}{l}\text { Head of } \\
\text { Application } \\
\text { and } \\
\text { Informatics } \\
\text { Diskominfo } \\
\text { Province }\end{array}$ \\
\hline 3 & $\begin{array}{l}\text { Compliance, } \\
\text { Audit, Risk, } \\
\text { and Security }\end{array}$ & $\begin{array}{l}\mathrm{PO} 2, \\
\mathrm{AI} 2\end{array}$ & $\begin{array}{l}\text { Head Section } \\
\text { of the } \\
\text { Encryption } \\
\text { and Security } \\
\text { Diskominfo } \\
\text { Province }\end{array}$ \\
\hline 4 & $\begin{array}{l}\text { Head IT } \\
\text { Administration }\end{array}$ & $\begin{array}{l}\text { PO6, } \\
\text { AI3, } \\
\text { AI5 }\end{array}$ & $\begin{array}{l}\text { Head Section } \\
\text { of Application } \\
\text { Development } \\
\text { Diskominfo } \\
\text { Province }\end{array}$ \\
\hline 5 & $\begin{array}{l}\text { Project } \\
\text { Manager } \\
\text { Owner }\end{array}$ & $\begin{array}{l}\text { AI2, } \\
\text { AI5 }\end{array}$ & $\begin{array}{l}\text { Head of } \\
\text { Informatics } \\
\text { Applications }\end{array}$ \\
\hline 6 & $\begin{array}{l}\text { Business } \\
\text { Process Owner }\end{array}$ & $\begin{array}{l}\text { AI2, } \\
\text { AI4, } \\
\text { AI7, } \\
\text { DS7 }\end{array}$ & $\begin{array}{l}\text { Head of } \\
\text { Diskominfo } \\
\text { Province }\end{array}$ \\
\hline 7 & $\begin{array}{l}\text { Head } \\
\text { Operations }\end{array}$ & $\begin{array}{l}\text { AI3, } \\
\text { AI4, } \\
\text { AI5, } \\
\text { AI7, } \\
\text { DS8 }\end{array}$ & $\begin{array}{l}\text { Head of } \\
\text { Application } \\
\text { and } \\
\text { Information } \\
\text { Technology, } \\
\text { Head of ICT } \\
\text { Infrastructure, } \\
\text { Head of Data } \\
\text { and Statistics } \\
\text { Management }\end{array}$ \\
\hline 8 & $\mathrm{CIO}$ & $\begin{array}{l}\text { PO6, } \\
\text { AI7, } \\
\text { DS7 }\end{array}$ & $\begin{array}{l}\text { Head of } \\
\text { Diskominfo } \\
\text { Province }\end{array}$ \\
\hline 9 & CEO & AI5 & Governor \\
\hline 10 & $\begin{array}{l}\text { Training } \\
\text { Department }\end{array}$ & $\begin{array}{l}\text { AI4, } \\
\text { DS7 }\end{array}$ & $\begin{array}{l}\text { Head Section } \\
\text { of ICT } \\
\text { Governance } \\
\text { and } \\
\text { Empowerment } \\
\text { Diskominfo } \\
\text { Province }\end{array}$ \\
\hline 11 & $\begin{array}{l}\text { Service } \\
\text { Desk/Incident } \\
\text { Manager }\end{array}$ & DS8 & $\begin{array}{l}\text { ICT } \\
\text { Governance } \\
\text { and } \\
\text { Empowerment } \\
\text { Section }\end{array}$ \\
\hline
\end{tabular}

\begin{tabular}{|c|l|l|l|}
\hline & & & $\begin{array}{l}\text { Diskominfo } \\
\text { Province }\end{array}$ \\
\hline 12 & $\begin{array}{l}\text { Deployment } \\
\text { Team }\end{array}$ & AI4 & $\begin{array}{l}\text { ICT } \\
\text { Governance } \\
\text { and } \\
\text { Empowerment } \\
\text { Section } \\
\text { Diskominfo } \\
\text { Province }\end{array}$ \\
\hline
\end{tabular}

\section{Conducting Audit}

The maturity measurement is started to fill the audit working paper based on case study observation and interviews with people that are already mapped in table 1 . The result of observation and interview is to fill the audit working paper. After completing all IT process measurements, the result of the maturity level is found.

Started from business goal 14, there are 18 IT processes that need to measure mapped from 5 IT Goal; it can be seen in figure 4. Mapping business goal 14 to IT processes.

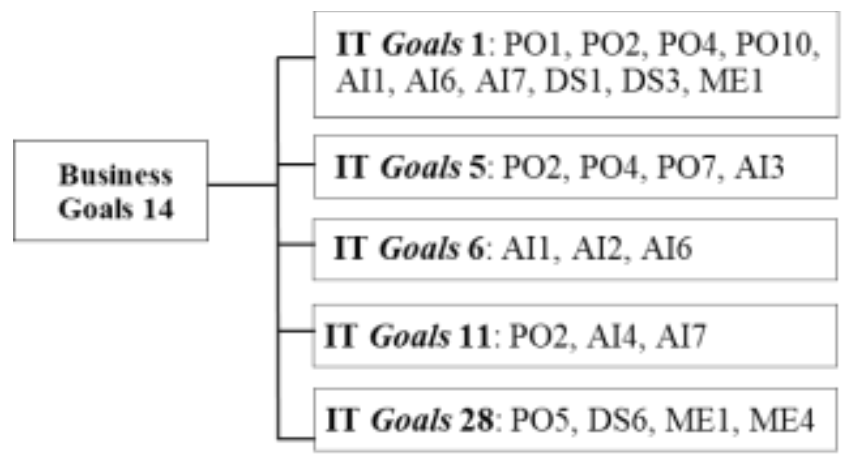

Fig. 4. Mapping BG14 to IT Processes

Then continue to business goal 15; 11 IT processes need to measure mapped from 4 IT Goal; it can be seen in figure 5 . Mapping business goal 15 to IT processes.

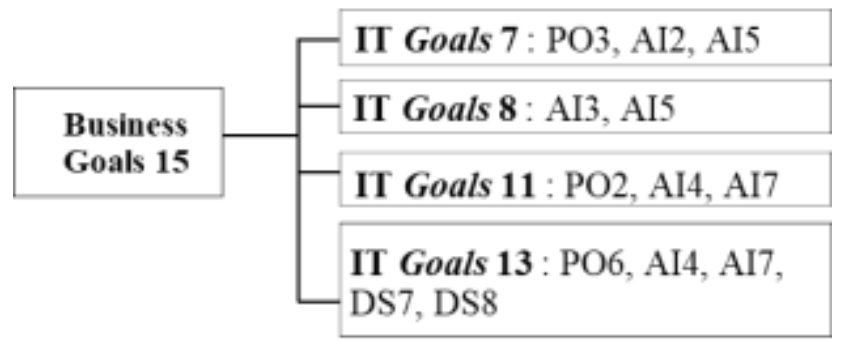

Fig. 5. Mapping BG15 to IT Processes

They measure each IT Process by fill an audit working paper. Here is the template to fill the audit working paper.

International Journal of Computer, Network Security and Information System (IJCONSIST)

Vol: 2, Issue: 2, March 2021, pp. 45-52 


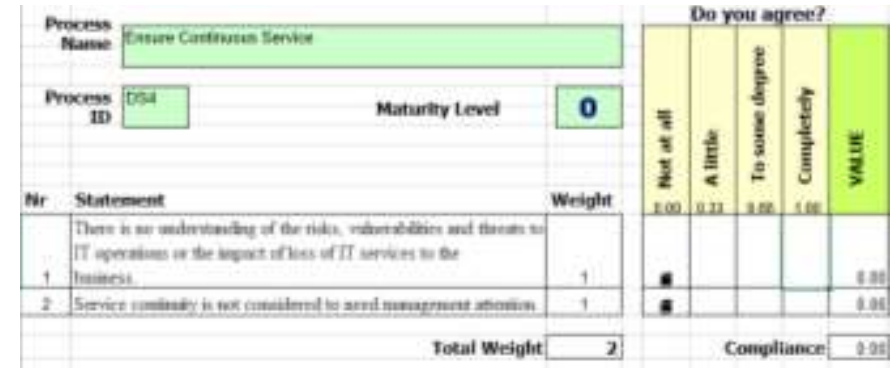

Fig. 6. Audit working paper

Figure 6 shows that each IT process should convert to quantitative measurement to ease the maturity level measurement. Each IT process has six maturity level; they are; maturity level 0 , maturity level 1 , maturity level 2 , maturity level 3, maturity level 4, and last but not least, maturity level 5 .

At each maturity level, it has a different statement to complete each maturity level. Figure 6 shows that maturity level 0 has two statements to accomplished. Each statement needs to be weighted. If the auditor said that the statement is important, it shold be weighted to one, and if it said that not an important process, it should be weighted by 0 . So, each maturity level has a total statement weight.

The next step is to give the score to each statement. If the auditor disagrees with this statement, it should be checked at point 0.00 . if the auditor agrees with the statement, it should be checked at 1.00. or if the condition is in the middle of 0.00 to 1.00 , it should be considered case by case. So, each statement has value by crossing' statement weights' and 'agreement score'.

After completing the score of each statement, the next step is to get the compliance score to each maturity level. The compliance is from the summary of the agreement score divide with the total weight of the statement.

Those steps are loop for each maturity level so that each level has its own compliance score. The next step is to measure the maturity level of the IT Process. The detailed process is described below.
DS4 Ensure Continuous Service

\begin{tabular}{|c|c|c|c|}
\hline Level & Compliance & Normalise & Contribution \\
\hline 0 & 0.0000 & 0.0000 & 0.0000 \\
\hline 1 & 1.0000 & 0.3333 & 0.3333 \\
\hline 2 & 1.0000 & 0.6667 & 0.6667 \\
\hline 3 & 1.0000 & 1.0000 & 1.0000 \\
\hline 4 & 1.0000 & 1.3333 & 1.3333 \\
\hline 5 & 1.0000 & 1.6667 & 1.6667 \\
\hline & & Maturity Level & 5.0000 \\
\hline
\end{tabular}

Fig. 7. Measuring maturity level

Figure 7 shows how to measure the maturity level. After completing the compliance score of each maturity level, the next step is to normalize each compliance score.

$$
\text { Normalize }=\text { level } / 15 * 5
$$

Equation 1 is how to normalize each level. The level is from 0 to 5,15 is from total level $(0+1+2+3+4+5)$, and 5 is from the maximum level of maturity. If the level is in level two, it would be counted as $2 / 15 * 5$, so the normalized score is 0.6667 , and so on until it finishes at level five.

The next column is to fill the contribution score, the calculation, as seen in (2).

$$
\text { Contribution }=\text { compliance } * \text { normalize }
$$

And the last one of each IT process is maturity level score. The maturity level is the summary of contribution from level 0 to 5 .

After measure all IT processes maturity level, it could summarize the result of the maturity level. The summary of the maturity level of business goal 14, as can be seen in table II summary of business goal 14. From table II PO4 and AI7 id at maturity level 2. PO1, PO2, PO5, PO7, AI3, AI4, Ds6, and ME4 is at Maturity level 3. At the same time, PO10 is at maturity level 4, otherwise AI6 at lowest among all that is at maturity level 1 .

TABLE II.

SUMMARY OF BG14

\begin{tabular}{|c|c|}
\hline $\begin{array}{c}\text { IT } \\
\text { Process }\end{array}$ & $\begin{array}{c}\text { Maturity } \\
\text { Level }\end{array}$ \\
\hline $\mathrm{PO} 1$ & 3.3587 \\
\hline $\mathrm{PO} 2$ & 3.3548 \\
\hline $\mathrm{PO} 4$ & 2.6281 \\
\hline $\mathrm{PO} 5$ & 3.3308 \\
\hline
\end{tabular}

International Journal of Computer, Network Security and Information System (IJCONSIST) Vol: 2, Issue: 2, March 2021, pp. 45-52 


\begin{tabular}{|c|c|}
\hline PO7 & 3.5493 \\
\hline PO10 & 4.4776 \\
\hline AI1 & 2.4149 \\
\hline AI2 & 2.9683 \\
\hline AI3 & 3.4045 \\
\hline AI4 & 3.0623 \\
\hline AI6 & 1.2446 \\
\hline AI7 & 2.5300 \\
\hline DS1 & 2.6824 \\
\hline DS3 & 2.4192 \\
\hline DS6 & 3.5316 \\
\hline ME1 & 2.7648 \\
\hline ME4 & 3.4409 \\
\hline Average & $\mathbf{3 . 0 0 9 6}$ \\
\hline
\end{tabular}

The summary of the maturity level of business goal 15 , as can be seen at table III summary of business goal 15 . The average is at maturity level 3, they are PO2, PO3, PO6, AI2, $\mathrm{AI} 3, \mathrm{AI} 4, \mathrm{AI} 5$, and DS7. Otherwise the IT process AI7 and DS8 is at maturity level 2.

TABLE III. SUMMARY OF BG15

\begin{tabular}{|c|c|}
\hline $\begin{array}{c}\text { IT } \\
\text { Process }\end{array}$ & Maturity Level \\
\hline PO2 & 3.3644 \\
\hline PO3 & 3.0650 \\
\hline PO6 & 3.0903 \\
\hline AI2 & 3.0388 \\
\hline AI3 & 3.2912 \\
\hline AI4 & 3.0400 \\
\hline AI5 & 3.0400 \\
\hline AI7 & 2.7133 \\
\hline DS7 & 3.0457 \\
\hline DS8 & 2.3667 \\
\hline Average & $\mathbf{3 . 0 0 5 5}$ \\
\hline
\end{tabular}

From table II. Summary of business goal 14 can be seen with a chart, as seen in figure 8 , from table II PO4 and AI7 id at maturity level 2. PO1, PO2, PO5, PO7, AI3, AI4, Ds6, and ME4 is at Maturity level 3. At the same time, PO10 is at maturity level 4, otherwise AI6 at lowest among all that is at maturity level 1.

\section{Maturity Level of BG14}

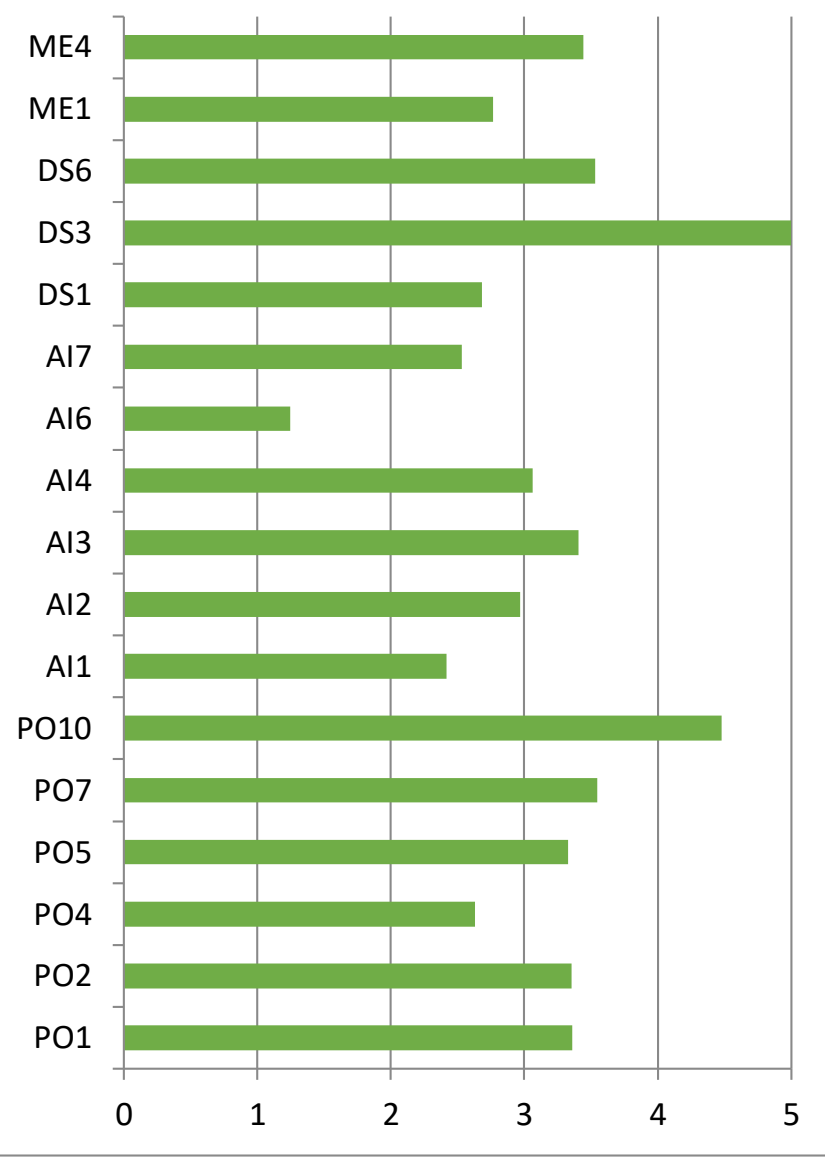

Fig. 8. Chart of maturity level BG14

From table III. Summary of business goal 14 can be seen with a chart, as seen in figure 9. The average is at maturity level 3, they are PO2, PO3, PO6, AI2, AI3, AI4, AI5, and DS7. Otherwise, the IT process AI7 and DS8 is at maturity level 2. 
MATURITY LEVEL OF BG15

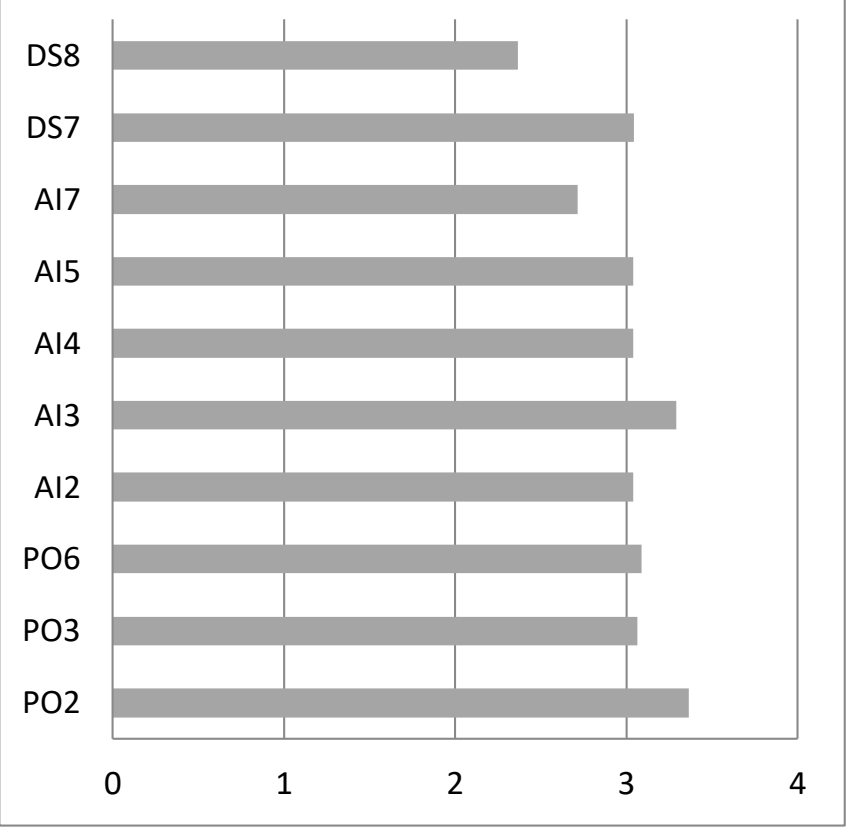

Fig. 9. Chart of maturity level BG15

\section{CONCLUSIONS}

After completing the working paper, the average of Business Goal 14 is at level 3.010, and Business Goal 15 at level 3.005. Thus points indicate the position of the maturity IT process implemented. Those point doesn't need to roundup; however, it needs to round down to integer, because it shows processes that have been checked.

Level 3 means Defined Process; it indicates that documentation of procedures is carried out, procedures have been standardized. The procedure has been communicated through training. There are still some minor deviations, but they are likely to be detected. The procedure is not very sophisticated, but it is still a formalization of the existing practice.

The conditions Defined Process in Cobit 4.1 define that the Provincial Diskominfo has policies related to standardization and documentation that are understood and agreed upon by all levels of the company. There are deficiencies regarding service and human resource productivity related to IT implementation that can be identified, and solutions are found to solve them, although not in their entirety because some procedures are informal.

\section{REFERENCES}

[1] P. Wallace, Introduction to Information Systems, Second Edi. Pearson Education, Inc., publishing,
2015.

[2] J. A. O'Brien and G. M. Marakas, Introduction to Information Systems, Fifteenth. McGraw-Hill Irwin, 2007.

[3] R. K. Rainer and C. G. Cegielski, "Introduction to Information Systems, Supporting \& Transforming Business," pp. 1-580, 2010, [Online]. Available: https://fahad913.files.wordpress.com/2017/06/introd uction-to-information-systems-supporting-andtransforming-business.pdf.

[4] R. K. Rainer, B. Prince, and C. G. Cegielski, Introduction to information systems : supporting and transforming business. 2011.

[5] D. Whiteley, An Introduction to Information Systems. 2013.

[6] R. M. Solow, "We'd Better Watch out," The New York Times, pp. 114-124, 2010.

[7] S. Mukaromah and A. B. Putra, "Maturity level at university academic information system linking it goals and business goal based on COBIT 4.1," in MATEC Web of Conferences, May 2016, vol. 58, doi: 10.1051/matecconf/20165803009.

[8] E. Brynjolfsson and S. Yang, "Information Technology and Productivity: A Review of the Literature," Adv. Comput. Acad. Press, vol. 43, no. 8, pp. 179-214, 1996.

[9] A. P. Subriadi, D. Hadiwidjojo, Djumahir, M. Rahayu, and R. Sarno, "Information technology productivity paradox: A resource-based view and information technology strategic alignment perspective for measuring information technology contribution on performance," J. Theor. Appl. Inf. Technol., vol. 54, no. 3, pp. 541-552, 2013.

[10] IT Governance Institute., COBIT 4.1. IT Governance Institute, 2007.

[11] R. K. Rainer, B. Prince, and C. G. Cegielski, Introduction to Information Systems, 5th Edition: Fifth Edition, vol. 12. John Wiley \& Sons, 2013.

[12] J. S. Topper and N. C. Horner, "Model-Based Systems Engineering in Support of Complex Systems Development," vol. 32, no. 1, pp. 419-432, 2013.

[13] G. D. Everett and R. McLeod, Software Testing: Testing Across the Entire Software Development Life Cycle. 2006.

[14] S. Mukaromah and A. Pribadi, "Information System Audit Based on Customer Perspective 4," Adv. Sci. Lett., vol. 23, no. 12, pp. 12309-12312, 2018, doi: 10.1166/asl.2017.10627.

[15] S. Mukaromah and A. B. Putra, "Maturity Level At University Academic Information System Linking It Goals And Business Goal Based On Cobit 4.1," doi: 10.1051/conf/2016.

International Journal of Computer, Network Security and Information System (IJCONSIST)

Vol: 2, Issue: 2, March 2021, pp. 45-52 
[16] S. Mukaromah and A. P. Subriadi, "The Significant of Cobit Mapping Business Goal 12 and IT Goal 19 (Case Study: Stikom Surabaya),” 2015.

[17] ISACA, "IS Standards, Guidelines and Procedures for Auditing and Control Professionals," Isaca, no. Jan. pp. 1-161, 2009.

[18] J. Henderson and N. Venkatraman, "Strategic Alignment: A Model for Organizational Transformation via Information Technology," 1990.

[19] D. L. Cannon, CISA: Certified Information Systems Auditor Study Guide. 2008.

[20] C. Nandhany, S. Mukaromah, and A. Pratama, "Perancangan Perangkat Pengukuran Maturity," J. Inform. dan Sist. Inf., vol. 1, no. 1, pp. 183-191, 2020.

[21] N. A. Taqiya, S. (Universitas P. N. "Veteran" J. Ti. Mukaromah, and A. Pratama, "Perancangan Perangkat Pengukuran Tingkat Kematangan Business Goal 14 Framework," J. Inform. dan Sist. Inf., vol. 1, no. 1, pp. 206-214, 2020.

[22] S. Mukaromah and A. Brastama, Cobit maturity level at PT KAI DAOP 8 Surabaya. .

[23] R. (Ronald) Weber, Information systems control and audit. Prentice Hall, 1999.

[24] N. Abda Taqiya, S. Mukaromah, and A. Pratama, "Analisis Tingkat Kematangan Spbe Di Dinas Komunikasi Dan Informatika Jawa Timur.”

[25] S. Mukaromah and A. B. Putra, "Maturity level at university academic information system linking it goals and business goal based on COBIT 4.1," in MATEC Web of Conferences, 2016, vol. 58, doi: $10.1051 /$ matecconf/20165803009.

[26] C. Nandhany, S. Mukaromah, and A. Pratama, "Analisis Maturity Level Layanan dan Produktivitas Sumber Daya Manusia berdasarkan Business Goal 15 COBIT 4.1 (Studi Kasus: Dinas Komunikasi dan Informatika Provinsi Jawa Timur),” J. Repos., vol. 2, no. 5, p. 667, 2020, doi: 10.22219/repositor.v2i5.887. 